\title{
History of occupational medicine: relevance of Imhotep and the Edwin Smith papyrus
}

\author{
P W BRANDT-RAUF ${ }^{1}$ S I BRANDT-RAUF ${ }^{2}$
}

From the Department of Medicine and Division of Environmental Sciences ${ }^{1}$ and Center for the Study of Societ $\vec{\Phi}$ and Medicine, ${ }^{2}$ Columbia-Presbyterian Medical Center, New York, New York 10032, USA

The origins of the recorded history of occupational medicine are usually dated to the time of Hippocrates (c 460 BCE-c 370 BCE). ${ }^{12}$ Hippocrates's admonition to his followers to observe the environment of their patients was complemented by his descriptions of the diseases of certain occupations including those of metallurgists, fullers, tailors, horsemen, farmhands, and fishermen. ${ }^{12}$ Before Hippocrates in the history of occupational medicine, reference is sometimes made to the fact that the study of the diseases of occupations is as old as man and his work; in certain texts considerable attention is paid to the work and related hazards of primitive and prehistoric peoples. ${ }^{3}$ The transition in the history of occupational medicine from prehistory to the recorded history of Hippocrates, however, passes over a body of writing with acknowledged relevance to the general history of medicine, the Egyptian papyri. ${ }^{4}$ These writings have special relevance to the recorded history of occupational medicine as well.

\section{Importance of Egyptian medical papyri}

There are eight major ancient Egyptian medical papyri-Kahun, Edwin Smith, Ebers, Hearst, Erman, London, Berlin, and Chester Beatty-dating from c $1900 \mathrm{BCE}$ to $\mathrm{c} 1200 \mathrm{BCE}^{4}$ The relevance of these papyri to the history of other medical specialties - for example, the Ebers Papyrus to medicine, ${ }^{45}$ the Kahun, Berlin, and London papyri to obstetrics and gynaecology, ${ }^{45}$ and the Edwin Smith papyrus to surgery and orthopaedics ${ }^{46}$ is well established. Nevertheless, the importance of these papyri to the history of occupational medicine has been largely unexplored.

Of particular importance is the Edwin Smith papyrus. The extant copy of this papyrus was transcribed c 1600 BCE in the XVIII dynasty of the New Kingdom. ${ }^{4}$ This copy was buried with its owner in a rock tomb at Thebes and unearthed in 1862 by grave robbers who sold it to the accomplished British Accepted 3 April 1986
Egyptologist Edwin Smith (1822-1906). ${ }^{46}$ Smithis daughter donated the papyrus to the New York Historical Society on his death, and it is now housed at the New York Academy of Medicine. ${ }^{4}$ Professogr James H Breasted (1865-1935) completed the definitive study of the papyrus in $1930 .^{7}$

The Edwin Smith papyrus is a roll over 15 feet lo with writing on both sides consisting of 22 columns $\overline{8} \mathrm{r}$ nearly 500 lines of text. ${ }^{7}$ The text contains 48 illustre tive cases dealing with various traumatic and accitdental injuries to the head, face, neck, arms, chese, shoulder, and spinal column, in that order. Each case is arranged in logical, quite modern fashion includiog a descriptive heading or provisional diagnosis, resu of examination, diagnosis, prognosis, treatment, a glosses on archaic terms used. ${ }^{7}$

Although the current copy dates from c 1600 BC the scribe at that time was clearly copying from $\overrightarrow{\sigma^{a}}$ much older document. Judging from the nature of the glosses introduced to explain archaic terminology, the original document may be dated as early as c $30 \overrightarrow{00}$ $\mathrm{BCE}$ to $\mathrm{c} 2500 \mathrm{BCE} .^{47}$ On this basis, the papyrus has been attributed by some to the most famous of eany Egyptian physicians, Imhotep (c $2780 \mathrm{BCE}) .^{67}$

Imhotep was the chief vizier to the pharoah Zoser. who was the first king of the Third Dynasty of the OBd Kingdom. In addition to filling this lofty administrative position, Imhotep was known as an astrologer, priest, architect, and engineer of the step pyramid Sakkara and as a surgeon. ${ }^{58}$

\section{Injuries at the pyramids}

As a physician and an administrator concerned win a major construction project, Imhotep would haye been in a position not unfamiliar to some physiciangs of occupational medicine of today. It is known thigt the work crews on the pyramid were subject to injugy moving and lifting the great stone blocks and thiy they received medical care. ${ }^{8}$ It is postulated thot Imhotep took advantage of this position $\overrightarrow{\mathrm{g}}$ administrator-engineer-physician to study systerox- 


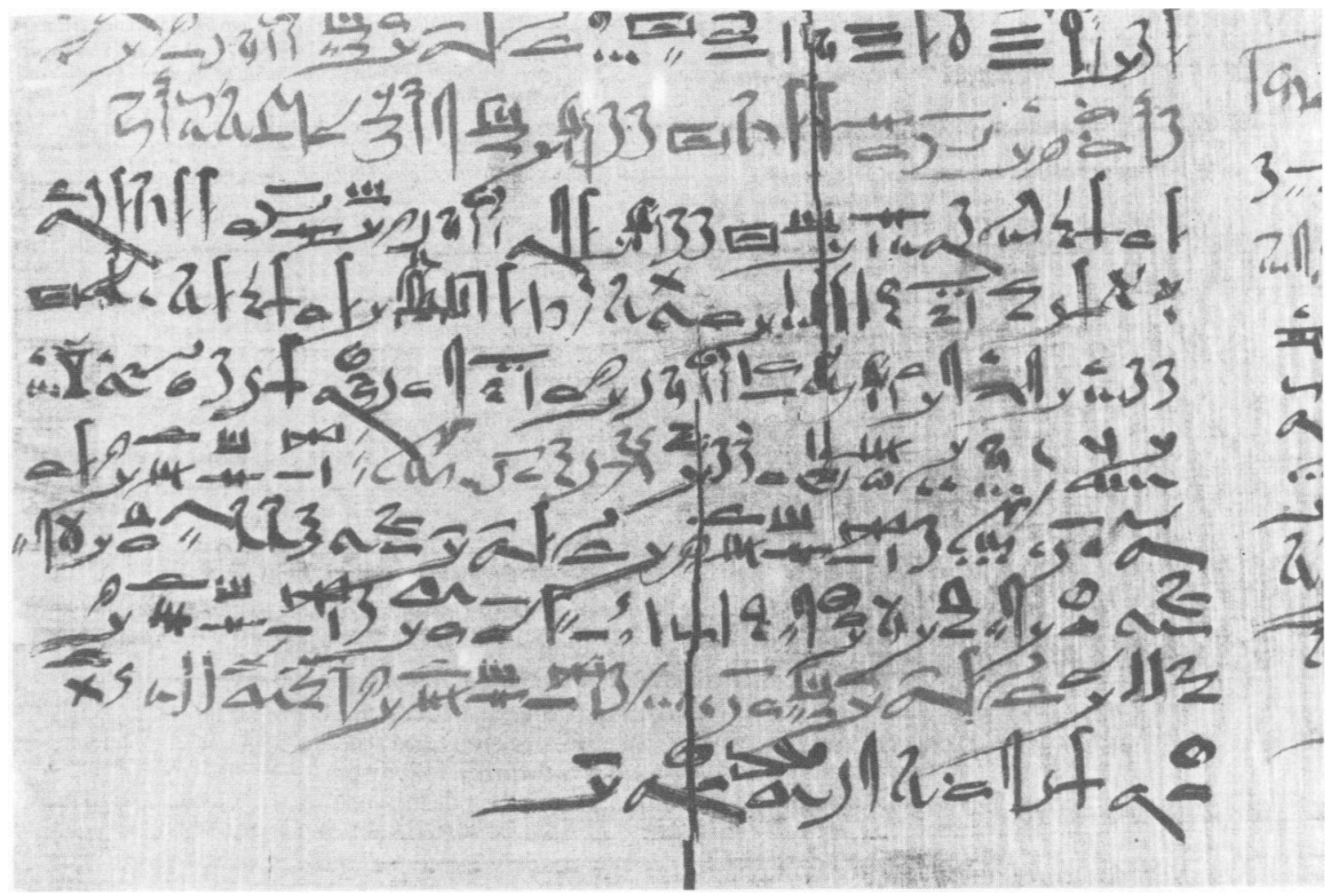

Final portion of the Edwin Smith papyrus containing the incomplete case of back pain (courtesy of the New York Academy of Medicine).

atically the injuries sustained by the workers during the construction of the pyramid, and that these observations formed the basis for the papyrus which later became the Edwin Smith document. ${ }^{67}$ Certainly, some cases in the Edwin Smith papyrus would be consistent with descriptions of occupational trauma to workers engaged in heavy construction.

If this is correct it seems evident that Imhotep confronted many of the same occupational injuries that face modern industrial physicians. Particularly intriguing from the point of view of occupational medicine is the final case described in the papyrus which deals with back pain ${ }^{7}$ (figure).

TITLE

Instructions concerning a sprain of a vertebra [in] his spinal column.

\section{EXAMINATION}

If thou examinest [a man having] a sprain in a vertebra of his spinal column, thou shouldst say to him: "Extend now thy two legs [and] contract them both [again]." When he extends them both he contracts them both immediately because of the pain he causes in the vertebra of his spinal column in which he suffers.

\section{AGNOSIS}

Thou shouldst say concerning him: "One having a sprain in a vertebra of his spinal column. An ailment which I will treat."

\section{TREATMENT}

Thou shouldst place him prostrate on his back; thou shouldst make for him... Unfortunately for modern medicine the case is incomplete. To this day, the answer to the appropriate management of back pain remains a major enigma in occupational medicine. "Plus ça change, plus c'est la meme chose."

In sum, it appears that the ancient Egyptian medical literature has considerable relevance to occupational medicine. Perhaps we should even regard the Edwin Smith papyrus as the first manual of occupational trauma and Imhotep as the grandfather of occupational medicine. 


\section{References}

1 Goldwater LJ. Historical highlights in occupational medicine. (Readings and perspectives in medicine booklet No 9, medical history program, the Trent collection and the Occupational Medicine Service.) Durham, North Carolina: Duke University Medical Center, 1985:1.

2 Rom WN. Environmental and occupational medicine. Boston: Little, Brown and Company, 1983:3.

3 Hunter D. The diseases of occupations. London: Hodder and Stoughton, 1978:1-61.
4 Leake CD. The old Egyptian medical papyri. Lawrence, Kansa University of Kansas Press, 1952.

5 McGrew RE. Encyclopedia of medical history. New York McGraw-Hill, 1985:105-6.

6 Beasley AW. The origins of orthopaedics. $J R$ Soc Med 1982;72:648-55.

7 Breasted JH. The Edwin Smith papyrus: published in facsimile an hieroglyphic transliteration with translation and commentary two volumes. Chicago: University of Chicago Press, 1930. 8 Cormack M. Imhotep, builder in stone. New York: F Watts, 196?.

\section{Destruction of manuscripts}

From 1 July 1985 articles submitted for publication will not be returned. Authors whose papers are rejected will be advised of the decision and the manuscripts will be kept under security for three months to deal with any inquiries and then destroyed. 